\title{
Exploring the Factors for Effective Sustainability Reporting: A Survey of Indian Chemical Industry
}

\author{
Pradip Kumar Mitra ${ }^{1}$, Vijay Agrawal $^{2} \&$ Aurobindo Ghosh ${ }^{3}$ \\ ${ }^{1}$ Vivekan and Education Society Institute of Management Studies and Research, Mumbai, India \\ ${ }^{2}$ Birla Institute of Technology, Mesra, Ranchi, India \\ ${ }^{3}$ ICFAI University, Vadodara, Gujarat, India
}

Correspondence: Pradip Kumar Mitra, Vivekanand Education Society Institute of Management Studies and Research, Hashubhai Advani Memorial Complex, 495-497, Collector's Colony, Chembur, Mumbai, India. Tel: 91-909-907-3959. E-mail: debolina456@yahoo.co.in

\author{
Received: October 9, 2014 Accepted: November 6, 2014 Online Published: December 30, 2014 \\ doi:10.5539/ass.v11n3p197 URL: http://dx.doi.org/10.5539/ass.v11n3p197
}

\begin{abstract}
Sustainability reporting is nowadays considered to be an important tool to showcase the environmental social and economic performance of an organization. Although different frameworks for reporting are available the adoption of reporting are still less in numbers in India. The research paper aims at understanding the perception and awareness about sustainability reporting that prevails across the chemical industry in India and also tries to find the major drivers and impediments of effective sustainability reporting as perceived by the industry participants through empirical analysis. The paper also tries to identify the major factors on which the industry wants to report their sustainable performance through exploratory factor analysis. A survey was carried out in Gujarat and Maharashtra the two chemical industries infested states of India among the decision makers of different chemical firms responsible for firm's reporting of both financial and non-financial performance. The research shows that sustainability as a concept is welcome by the industry but as a reporting process it has failed to reach the desired level of reporting due to its complexity and therefore non acceptance. The research identifies the different factors on which the industry wants to report and also finds the most important drivers and the major problems of sustainability reporting.
\end{abstract}

Keywords: chemical industry, economic aspect, financial aspect, human aspect, natural aspect, social aspect, sustainable development, sustainability reporting, triple bottom line

\section{Introduction}

\subsection{Background of the Study}

Reporting on sustainable performance has become a global trend that insists companies to disclose their performance on economic, environment and social areas (GRI Guidelines, 2002).The most popular reporting framework on sustainability called Global Reporting Initiative (GRI) is being increasingly used across the world (Brown, Martin, \& Teodorina, 2007). Large companies are currently producing their reports as per GRI framework but SMEs have failed to respond to this reporting standard across the world. A sustainable development as a concept given by World Commission for Environment and Development (WCED) makes it necessary to protect the human civilization while the progress continues. The definition of sustainable development as proposed by WCED in 1987 says "Sustainable Development means meeting the needs of the present without compromising the ability of future generations to meet their own needs" (World Commission on Environment and Development, 1987). A sustainable society is a society which balances with the natural world from generation to generation without depleting its resource base by exceeding sustainable yields and never produces pollutants in excess of nature's capacity to absorb them (Wright, 2007a).

Indian Chemical industry has become a major driver for economic growth of the country and has made a major contribution towards social and economic development. In the last three decades the industry has grown tremendously specially in small scale sector with a wide range of products in its credit. Manufacturing of chemical products passes through a number of stages with variety of unit processes and operations and these results in production of process wastes of varying quality and quantity. So generation of chemical pollutants and 
untreated effluents has seriously disturbed the ecology in its surroundings leading to massive social and environmental hazards. So internally and externally a growing concern has emerged that the survival of chemical industry for a longer term will depend upon its progress towards economic, social and environmental sustainability (Chemistry Leadership Council, 2005). Chemical industry as a potential growth driver to Indian Economy should address sustainability issue for its long term sustainable growth.

Carter and Rogers (2008)were the pioneers to describe the term sustainability which is a three legged tool integrating People, Planet and Profit popularly known as Triple Bottom Line (TBL). Triple Bottom Line as a term was first introduced by Elkington in 1997 which states that Companies have an extended responsibility for environment and society. As an extension to this a sustainability report has emerged as a special corporate communication instrument that depicts the corporate values, principles and performance in all aspects of sustainability for the stakeholders (Cahyandito \& Ebinger, 2005). Through the sustainable development reports companies must provide a clear picture to internal and external stakeholders of the corporate position and also the activities carried out for environmental, social and economic development (WBCSD, 2002).Taking a note of this the number of sustainability reporting has started increasing over the years. Substantial increase in the number of companies publishing reports on its environmental and social front was found after the first separate environmental report was published in 1989 (Kolk, 2004a). Differentiation in the reporting in terms of countries and sectors was noticed but there was a continuous rise in the number of reporting with a clear inclination for the inclusion of societal and financial issues (Kolk, 2004b). In a recent international survey it was seen that most investors and financial research and rating agencies are finding these reports very useful for their professional work (Pleon, 2005).Global reporting output per year has grown tremendously from almost zero in 1992 to an expected 4000 reports in 2010 (Wensen, Wijnand, Johanna, \& Jutta, 2011).

\subsection{Importance of Sustainability Reporting for Indian Chemical Industry}

In India the sustainability reporting for chemical industry is yet to take pace. Only a handful of 14 companies from chemical industry are producing sustainability reports (Shekharan, 2012). The sustainability reporting is a voluntary disclosure and not a mandatory affair in India at present (Reddy, 2005). The industry is having 100\% FDI (Foreign Direct Investment) approval and mostly dominated by Small and Medium Scale Enterprises (SMEs).These enterprises comply with some environmental laws and regulations available in the state. More number of SMEs put pressure for more environmental performance so owners must develop a frame of mind to understand the circumstances that influence promoting a successful implementation of organisational changes that promotes superior environmental performance among SMEs (Cordano, Marshall, \& Silverman, 2010). Being a voluntary disclosure at present a consensus and a common framework has become necessary for the industry decision makers. Initiatives taken voluntarily can promote different industry and firm specific innovations which will help achieve the goal of environmental performance (Koski \& May, 2006).

The Indian Chemical industry is playing a crucial role in the Indian Economy (Department of Chemicals and Petrochemicals, 2008). The industry contributes to the Indian GDP about $6.7 \%$ which is $10 \%$ of total exports also(KPMG Chemtech Foundation, 2013). As per the Tata Strategic Management Group (TSMG) and Federation of Indian Chamber of Commerce and Industry(FICCI) the estimated size is at around US\$ 83 billion in 2010 approx., which is equivalent to $2.5 \%$ of World Chemical Industry (FICCI \& TSMG, 2010). The approximate investment made in Indian Chemical Business is US\$ 60 billion and 1 million employees are working in this segment. Contribution made by Indian chemical industry is approximately $13 \%$ to $14 \%$ of total exports and $8 \%$ to $9 \%$ of total imports. Further volume wise this industry ranks 12 th in the world and 3rd in Asia (Planning Commission, 2010a). A remarkable development has been witnessed that the industry is growing as an innovative industry. The per capita consumption of chemical products in India is $1 / 10$ th of the world average (Planning Commission, 2010b).

As per the report of Indian Chemical Industry in XIIth Five Year Plan the levels of pollutions have reached alarming proportions in most of the chemical industry clusters in India. There are some instances where some Indian Chemical Companies are doing well in the area of non-financial performance. But the non-compliant attitude of many companies as well as ineffective enforcement efforts in some clusters have led to large scale damage to the environment as the report suggested. According to Ministry of Environment and Forests, experience of industrially developed nations indicates that a $1 \%$ increase in GDP (Gross Domestic Product) leads to 1 to $3 \%$ increase in generation of hazardous waste (TSMG, 2012a). As per the report prepared by Tata Strategic Management Group in India on Industrial Hazardous Waste Management, India's hazardous waste inventory increased from 0.6 million tons in 1989 to an estimated 6 million tons in 2003, 7.8 million in 2008 and 9.1 million tons in 2011 alone, but this increase in hazardous waste volumes has not been accompanied by a commensurate increase in treatment and disposal facilities (TSMG, 2012b). Bhopal disaster is commonly known 
as Bhopal Gas Tragedy which is considered as the world's worst industrial disaster. Union Carbide India Limited (UCIL) a pesticide plant was the source of this disaster occurred on the night of 2-3 December 1984. As reported by Department of Chemicals and Petrochemicals in 2013 over 5 lakh people were affected by methyl isocyanate gas and other chemicals. The toxic substance made its way to the city when leaked and created havoc which made a death toll of 3787 as the report suggests. (Department of Chemicals and Petro Chemicals, 2013).

The above facts direct to the point that Chemical Industry is an inevitable organ for the economic growth of the country but at huge cost of deteriorating health, natural resources and welfare of society. A growing identification of sustainability is aimed towards a long human wellbeing and sustainability reporting practices will pave the way for the same (Wright, 2007b). Although sustainability reporting practices has taken pace in Indian Financial Reporting System but lot more to come especially in front of Chemical industry.

Empirical research was conducted to understand the different organisational contextual factors that might influence the nature and extent of corporate social reporting (Adams, 2002a). It was argued that although it was noticed that reporting process, attitude of participants and corporate culture play an important role in determining the accountability through corporate disclosure, theories related to social and environmental reporting were developed without engaging organizations that produces sustainability reports. Adams in 1998 carried out interviews with three British companies and four German companies and found that decision making and reporting process depends on country of origin, corporate size and corporate culture (Adams \& Patty, 2007a). In late 1997 an interview was conducted in 27 Irish public limited companies to understand managerial perceptions and motives for corporate social disclosure by O'Dwyer (2002). Larrinaga and Paez (2001) conducted case studies in nine Spanish organisations through $15 \mathrm{semi}$ structured interview to know the motives of disclosure of environmental information and perception of corporate environmental performance Adams (2004) pointed that increased size and increased awareness of the impacts of companies on the environment and local communities leads to greater corporate accountability. The above discussion leads to a point that understanding perceptions, awareness and motivations for sustainability reporting is practiced in other countries also and those studies contributed on theorising the concept for better performance.

\subsection{Identification of Different Aspects and Variables for Sustainability Reporting}

Through literature review and different available published reports on sustainability performances five major aspects were identified which a sustainability reporting addressed to as Human Aspect, Social Aspect, Natural Aspect, Economic Aspect and Financial Aspect. Further under those important aspects different factors were also identified which forms an integral part covering those aspects. As described by United Nations Development Program human aspect deals with human development through equity, empowerment and sustainability where people's choice can be expanded (UNDP, 2013). Seven variables were placed for survey are described below:

Development of employee: Encourage professional and technical development through continuous education and training for all employees and motivate them towards sustainable development issues which have got relevance with clients and business. The employees should be capable to use their talents and share their knowledge to find more sustainable solutions for the development of society.

Healthy People: It means creating healthy people in the society through reduction of carbon emission and protection of natural resources and environment. Helping communities to fight severe natural calamities and promoting healthy lifestyles will be the prime focus.

Educated Population: As education and sustainability are inextricably linked it always remains as a central theme for sustainable development. It means creating educated population by providing basic education to them and then reorienting the existing education in such a way so that public understanding and awareness is created to form a sustainable society.

Youth and Leadership: It means promoting the youth by making them leaders or change agents for the sustainable development of society by creating opportunities through some projects where they can work and show their innovation and leadership skills.

Active Volunteering: It means as an organization it must work in volunteer capacity to promote the cause for human development like donation to hospitals, schools, churches and temples and other charitable institution.

Artisan and Entrepreneurship: It means that organization will foster for economic and community development by promoting small cottage industries like pottery, design work, small cooperative farming etc. in rural areas. 
Stakeholder Accountability: Organization will create a sense of trust among stakeholders through transparent delivery of development and cooperation by improving their quality and effectiveness in delivering the development results.

Social aspects cover the social dimensions through which the companies exhibit their performances towards society's betterment through literacy improvement, arrangement of safe drinking water, opening up hospitals, improve sanitation facilities, carrying out relief efforts, building roads and hospitals (CAG Report No.9 on PSU, 2007). Under the social aspect six major variables were placed for discussion and survey.

Stakeholder Engagement: Through stakeholder engagement process the organization will include the stakeholders in the decision making process through dialogue so as to understand the stakeholders better for effective decision making and stakeholder accountability.

Enhancing Capacity: It is a conceptual approach to development that focuses on removing the obstacles of inhibited people and NGOs etc. by realizing their developmental goals and enhancing their abilities to perform for measurable and sustainable results.

Building Community: Organization will promote and develop small book clubs, arrange mass festival, create a chain of distribution and establish cooperative culture etc.

Creating Educational Institution: Organization will provide assistance to create institutions for promoting higher education on sustainability issues which in turn will blend the campus education with community development.

Forming Network: Organization will create facilities like online community service and training centre. This will help resolve the different social issues through online discussions and participations.

Improving Health Care and Sanitation: It means improving health care by creating small dispensary to provide basic medical facilities and to provide healthy drinking water at rural and industrial area. Maintaining a hygienic excreta and providing basic sanitation facilities can be arranged by the organisation which will create a clean and healthful living environment both at home and neighborhood of users.

Supply Chain at Base of Pyramid: Organization will involve poor communities in production process including the management of critical supply chain.

Natural aspects deals with preservation of ecosystem and natural environment as the entire human existence is dependent on it. Ecosystems support human life and economies with a range of different goods and services which should not be stressed by the dual demands of increasing population like depletion of water supplies, degrading agricultural soils, cutting of forests (Wright, 2007c). Five major variables under the natural aspect were placed for survey.

Biodiversity Restoration: Organization will help restoring eco system on earth by taking care and maintaining the natural environment where it will be allowed to regenerate and flourish. It means organization will support native plants and animals to live naturally in the area.

Greening Supply Chain: Organization will bring new technology through innovation which will improve the supply chain process by enhancing productivity with lesser cost and reduced usage of scarce resources.

Management of Scarce Resources: This means that organization will bring new innovation in extracting and processing of raw materials and scares resources.

Environmental Conservation: Environmental conservation can be promoted by an organization by paying farmers and foresters to provide protective vegetation near water supplies, purchasing lands around reservoirs, enforcing limits on growth and controlling the contamination of water and agricultural land.

Wildife Protection: Organizations can protect wild life by providing incentives to local communities to utilize wild life as a form of land use to ensure ecological preservation and sustainable economic development. They can help different NGOs which are trying to implement effective community based natural resource management.

Economic aspects is understood as a long term proposition where most companies try to increase their ability to contribute to their local community, society and whole planet in the long run along with their immediate financial performance (Doane \& Mac Gillivray, 2001). Four major variables were placed for discussion and survey.

Improve Employability: Organization will work hand in hand with universities to create illuminating pathways for the students through innovative learning. With industry guidance universities will play a decisive role in shaping future capabilities to address sustainable development. 
Regional Development: Through this process the organization will try to understand the regional needs and work for the economic growth of the region without creating negative impact on environment. A collaborative and streamlined activity with regional stakeholders will be the most crucial way to perform better.

Price Stabilization: Through this process organization will substantially reduce the effect of the business cycle on profit of chemical companies through various risk reduction measures and will create a strong link between input cost and output price.

Employment Generation: Providing new opportunities for employment and creating adequate number of quality jobs for the country's youth.

Financial aspects deal with value creation for the shareholders and generation of livelihood to contribute in a strategic way where prime focus is put on the development of brand equity, reputation, human capital and alliances (Fiksel, Low, \& Thomas, 2004). Three major variables were placed for survey.

Income Enhancement: Organization will try to increase the income by reducing the cost and risks through pollution prevention, reducing wastages and lower consumption of raw material. The product manufactured through this process will be eco-efficient and will generate more revenue for the firm through enhanced sales.

Enhancing Shareholders' Value: Reduction of wastage through efficient internal operation and achieving product stewardship through eco efficient process should be a priority. This will in turn send a very positive message to the external stakeholders who will enhance the legitimacy and reputation of the organization.

Livelihood Generation: Organizations will try to secure the basic needs of the workers like food water shelter and clothing.

\subsection{Formulation of Objective of Research}

The objective was to understand whether these aspects play any pre dominant role in sustainability reporting for Indian Chemical Industry as perceived by industry decision makers.

The objective of the research is formulated.

Objective I: To identify the important factors to be reported through sustainability reporting as perceived by Indian Chemical Industry through exploratory factor analysis.

Objective II: Understanding the perception and awareness of the various aspects of sustainability reporting at various categories of chemical industry in India.

Objective III: Researcher is interested to identify the most important drivers and major problems of sustainability reporting through empirical analysis with special reference to Indian Chemical Industry.

\section{Research Methodology}

\subsection{Identifying the Drivers and Problems Placed for Discussion}

The objective of research was to understand the awareness and perceptions about sustainability reporting for Indian Chemical Industry and finding the most important driver and problem of sustainability reporting. Six drivers were identified after examining the GRI Framework available and in consultations with the industry practitioners as i) Economics and business ii) People and population iii) Enabling technology iv) Regulation v) Environmental crisis vi) Global inequality. Drivers were then placed in the questionnaire to know how industry is going to rank them as an important driver for sustainability reporting. The selection of the problems for discussion was formulated on the back drop of the report "The State of Sustainability Reporting in Australia 2005" prepared by Centre for Australian Ethical Research in collaboration with KPMG (CAER, 2005). Adams \& Patty (2007b) through their action research on the basis of Kurt Lewin's integrated model of planned change listed out some impediments for sustainability reporting. These two reports formed the basis for formulating problems in the questionnaire of this research. The formulated problems were further discussed with practicing Indian counterpart to make it more aligned and relevant towards Indian context. The following problems were placed in the questionnaire.

Lack of legal framework

Lack of best practice guidance

Lack of leadership and innovation in sustainable development reporting

Absence of external motivation and enforcement mechanism

Lack of awareness and understanding among stakeholders 
Lack of awareness and understanding of implications at the top management level

\subsection{Research Process Followed}

The research was conducted by survey through questionnaire. Expert review was taken from 10 experts for changes after designing the draft questionnaire. Reliability test was conducted after modifying the questionnaire through a pilot survey of 40 respondents. Cronbach's Alpha score was more than 0.70 sufficient to justify the reliability of the questionnaire. Actual survey was then initiated by floating the questionnaire across the different category of chemical industry in Gujarat and Maharashtra. Chemical Industry as a sector can be categorised into different categories in terms of production of different items like dyes and pigments, pharmaceuticals, fertiliser and pesticides, petrochemical and other organic and inorganic chemicals. The hypothesis were formulated and tested. Different non-parametric tests Chi Square Test, Kruskal-Wallis Test, Spearman's rank correlation and Kendal's Tau Test were applied for testing the hypothesis. Exploratory factor analysis was carried out to identify the factors on which the industry decision makers are keen to report on.

\subsection{Sample Size and Sampling Procedure}

The research was conducted mainly at Gujarat a state of India as it is the highest contributor in Indian Chemical Industry in terms of output (53\%) and performance followed by Maharashtra (9\%) (Planning Commission, 2010c). Gujarat is a major hub of diversified chemical industry having 7000 large and medium scale units and 31000 small scale units (KPMG, 2007). So these two states become well representation for sample. The survey was carried out for a period of eight months. Responses were received from 520 respondents mainly the decision makers of financial reporting from the top management of the firm. The responses were then bifurcated in different categories of chemical firm as per their produced output.

The table below shows the different categories of chemical organization from which responses were received. The respondents were asked to provide information regarding the category of their organisation.

Table 1A. Frequency distribution of different chemical industry

\begin{tabular}{cccc}
\hline Industry & Frequency & Percent & Cumulative Percent \\
\hline Petrochemicals & 19 & 3.7 & 3.7 \\
Fertilizer \& Pesticides & 34 & 6.5 & 10.2 \\
Pharma & 52 & 10 & 20.2 \\
Dyes \& Pigments & 238 & 45.8 & 66 \\
Organic & 77 & 14.8 & 80.8 \\
Inorganic & 96 & 18.5 & 99.2 \\
Others & 4 & 0.8 & 100 \\
Total & 520 & 100 & \\
\hline
\end{tabular}

Gross monthly turnover (In Lakh): The respondents were asked regarding the gross monthly turnover of their organisation. Majority (59.1 percent) of the organisations have their gross monthly turnover between 25-500 lakh. 17.7 percent of the organisations are having their gross monthly turnover more than 1000 lakh. 17.7 percent of the organisations are having their gross monthly turnover between 500-1000 lakh. 5.4 percent of the organisations are having gross monthly turnover between 5- 25 lakh.

Table 1B. Turnover wise frequency distribution

\begin{tabular}{cccc}
\hline Turnover (In Lakh) & Frequency & Percent & Cumulative Percent \\
\hline $5-25$ & 28 & 5.4 & 5.4 \\
$25-500$ & 308 & 59.2 & 64.6 \\
$500-1000$ & 92 & 17.7 & 82.3 \\
More than 1000 & 92 & 17.7 & 100 \\
Total & 520 & 100 & \\
\hline
\end{tabular}

\section{Hypothesis Formulation, Testing \& Results}

3.1 Framing of Hypothesis and Testing

Hypothesis 1

$\mathrm{H}_{0}$ : Knowledge about Sustainability Reporting aspects and Category of an Organisation are independent of each other. The hypothesis was framed to understand if there is any significant difference that can be 
observed regarding the knowledge of sustainability reporting process across different category of the chemical industry. The cross tabulation (Table 3A \& 3B) between the observed and expected frequency and Pearson Chi-Square calculated value at 5 degree of freedom suggests null hypothesis to be rejected. Hence it can be concluded that Knowledge about Sustainability Reporting aspects and Category of an Organisation are not independent of each other. Inference can be drawn that there is significant difference of knowledge about sustainability reporting aspects across different category of chemical firms. From total counts one can say most of the respondents do not have the knowledge about sustainability reporting process.

\section{Hypothesis 2}

$\mathrm{H}_{0}$ : Belief about Sustainability Reporting aspects and Category of an Organisation are independent of each other.

The respondents were asked whether their organization believes about sustainability reporting. From the cross tabulation (Refer Table 4A \& 4B) showing observed and expected frequencies and The Pearson Chi-Square calculated value at 5 degree of freedom of 16.411 suggests that null hypothesis is rejected. Hence it can be concluded that Belief about Sustainability Reporting aspects and Category of an Organisation are not independent of each other. So the belief on sustainability was not found same across different categories of the organization. But in total it suggests that $91.5 \%$ respondents believe about sustainability reporting.

\section{Hypothesis 3}

$\mathrm{H}_{0}$ : Perception about Sustainability Reporting as a part of framework of Corporate Governance process and Category of an Organisation are independent of each other. The cross tabulation (Refer table 5A \& 5B) and the Pearson Chi-Square calculated value at 5 degree of freedom as 28.176 shows that the null hypothesis is rejected. Hence it can be concluded that Perception about Sustainability Reporting as a part of framework of Corporate Governance process and Category of an Organisation are not independent of each other. So it can be inferred that perception about sustainability reporting as a part of framework of corporate governance is not uniformly accepted across the different category of chemical firms. Over all it was found a substantial number of respondents (74.2\%) perceive sustainability reporting as a part of framework of corporate governance.

\section{Hypothesis 4}

$\mathrm{H}_{0}$ : Agreement with the proposition that a Sustainable Report should disclose both favourable and unfavourable results and Category of an Organisation are independent of each other. From the cross tabulation (Refer table 6A $\& 6 \mathrm{~B})$ ) and the Chi-Square calculated value at 5 degree of freedom of 28.176 the null hypothesis is rejected. So we can say that Agreement with the proposition that a Sustainable Report should disclose both favourable and unfavourable results and Category of an Organisation are not independent of each other. Hence inference can be drawn that across different category of chemical industry there is significant difference to agree on the proposition that sustainable report should disclose both favourable and unfavourable results. Majority (91.7\%) of the respondents were of the opinion that sustainability report should disclose both favourable and unfavourable results.

\section{Hypothesis 5}

$\mathrm{H}_{0}$ : Perception about issues relating to Sustainable Development and Reporting are relevant in the Indian context and Category of an Organisation are independent of each other.

Questions were asked whether the respondents perceive that sustainable development and reporting are relevant in Indian context or not. From the cross tabulation (Refer Table 7A) of observed and expected frequencies and the Pearson Chi-Square calculated value at 5 degree of freedom at 34.051 the null hypothesis is rejected. Hence it can be concluded that Perception about issues relating to Sustainable Development and Reporting are relevant in the Indian context and category of an Organisation are not independent of each other. Hence it implies that there is significant differences in the perception about relevance of sustainable development and reporting in Indian context across the different categories of chemical firms.

\subsection{Factor Analysis}

Factor Analysis was performed to identify the factors which play a predominant role in the Sustainability Reporting. The KMO value of 0.934 suggests that there is adequate number of factors that can be extracted and again the significant value of Bartlett's Test of Sphericity is 0.000 which is $<0.001$.So, the sample inter correlation matrix did not come from a population in which the inter correlation matrix is an identity matrix. (Table 15) 
Total Variance Explained: There were five factors extracted by using the method of principle component analysis and rotation method of Varimax with Kaiser Normalization with criteria Eigen value more than one (Refer Table 16 and 17). The result of factor analysis is shown below.

\begin{tabular}{|c|c|c|c|}
\hline Factor & Variables & $\begin{array}{l}\text { No of } \\
\text { Items }\end{array}$ & $\begin{array}{c}\text { Cronbach's } \\
\text { Alpha }\end{array}$ \\
\hline 1 & $\begin{array}{c}\text { Income Enhancement } \\
\text { Livelihood Generation } \\
\text { Improve Employability } \\
\text { Enhancing Shareholder Value } \\
\text { Price Stabilization } \\
\text { Regional Development } \\
\text { Employment Generation } \\
\end{array}$ & 7 & 0.959 \\
\hline 2 & $\begin{array}{c}\text { Biodiversity Restoration } \\
\text { Environmental Conservation } \\
\text { Healthy people } \\
\text { Greening Supply Chains } \\
\text { Management of Scarce } \\
\text { Resources } \\
\text { Wildlife Protection } \\
\text { Development of Employees } \\
\text { Active Volunteering } \\
\text { Stakeholder Accountability } \\
\text { Educated population }\end{array}$ & 10 & 0.936 \\
\hline 3 & $\begin{array}{c}\text { Creating Educational and } \\
\text { Charitable Institutions } \\
\text { Community Development } \\
\text { Enhancing Capacity } \\
\text { Supply chain as a base of } \\
\text { pyramid } \\
\text { Forming Networks } \\
\end{array}$ & 5 & 0.906 \\
\hline 4 & $\begin{array}{c}\text { Youth \& Leadership } \\
\text { Artisan \& Entrepreneurship } \\
\text { Development } \\
\text { Stakeholder Accountability }\end{array}$ & 3 & 0.8 \\
\hline 5 & $\begin{array}{l}\text { Improving Health care and } \\
\text { sanitation }\end{array}$ & 1 & N.A \\
\hline
\end{tabular}

\subsection{Formulation of Hypothesis and Testing Related to Factors}

\subsubsection{Hypothesis 6}

Ho: There is no significant difference in playing a predominant role by major factors in Sustainability Reporting at different categories of organisation.

To measure the hypothesis non parametric test was necessary. So test of normality was conducted on five major factors identified for reporting.

\subsubsection{Test of Normality}

The Factor scores of different identified aspects of reporting were tested for Normality. Hypothesis

$\mathrm{H}_{0}$ : The Distribution is normally distributed.

$\mathrm{H}_{1}$ : The Distribution is not normally distributed.

All five factors are not found normally distributed at 5 per cent level of significance. Hence it would be appropriate to perform non-parametric test on these different factors (Refer Table 8).

The non-parametric test- Kruskal-Wallis test has been performed and the result is shown below. The result shows the mean rank of different categories of organisations. In the table (9A \& 9B), the calculated Chi-Square, degree of freedom, and significant value is given. Factor 1, 2, 3 and 5 are found significant at $5 \%$ level of significance and Factor 4is not found significant at $5 \%$ level of significance. Hence it can be concluded that for Factor 1, 2, 3 and 5 there is a significant difference in playing a predominant role in Sustainability Reporting at different categories of organisation. And for Factor 4 there is no significant difference in playing a predominant role in Sustainability Reporting at different categories of organisation.

\subsubsection{Hypothesis 7}

Ho: There is no significant difference in playing a predominant role by different factors in Sustainability Reporting at different categories of gross monthly turnover.

The non-parametric test- Kruskal Wallis test has been performed and the result (Refer Table 10A \& 10B) shows the mean rank of different categories of gross monthly turnover for five major factors of reporting. In the table, 
the calculated Chi-Square, degree of freedom, and significant value is given. Factor 1, 3 and 5 are found significant at $5 \%$ level of significance and Factor 2 and 4 are not found significant at $5 \%$ level of significance. Hence it can be concluded that for Factor 1, 3 and 5 there is a significant difference in playing a predominant role in Sustainability Reporting at different categories of gross monthly turnover. And for Factor 2 and 4 there is no significant difference in playing a predominant role in Sustainability Reporting at different categories of gross monthly turnover. From mean rank, it can be concluded that Factor 1 plays more important role in the organisations having gross monthly turnover more than 1000 lakhs whereas Factor 3 plays more important role in the organisations having gross monthly turnover of 5-25 lakhs.

\section{Discussion \& Conclusion}

The conduct and outcome of the study came out with some meaningful insights on the current status of sustainability reporting in Indian Chemical Industry. The empirical evidence from the research revealed an interesting finding that respondents are not very much aware of the different aspects of sustainability reporting process but they sincerely believe that sustainability reporting should be an integral part of corporate governance in India. This shows that if a consensus can be achieved how to report the sustainable performances through discussions with the stakeholders specifically at small and medium enterprises level more meaningful framework can be created which might be well accepted by the industry. Across the different categories of chemical firms significant difference was found in perception and belief towards sustainability reporting. But in totality there was found a positive frame of mind towards the importance and acceptance of sustainability reporting as a framework for corporate governance.

\subsection{Result of Factor Analysis}

The exploratory factor analysis suggests that the most important factor is factor 1 which explains 51 percent of the total variance, followed by factor 2, 3, 4 and 5. The five factors explain 76 percent of the total variance. Again the five factors are found reliable through reliability analysis. Factor 1 includes all the variables decided under the economic and financial aspects. Factor 2 includes all the major variables identified under natural aspects and human aspects followed by factor 3 which is dominated by the variables identified under social aspects. Factor 4 and 5 deals with some of the variables mentioned in human and social aspects. While analysing on basis of turnover economic and financial aspect (Factor1) were found playing more important role in companies having high turnover and social aspect (Factor 3) was found playing major role in companies having lower turnover.

\subsection{Most Important Drivers}

The research focused on the identification of most prominent driver for sustainability reporting as perceived by the industry. At the same time the most important problems for sustainability reporting were also tried to be identified with the ranking of nature of problems across the board. The descriptive statistics of different drivers for sustainable development is given in Table 11 shows that most important driver is economics and business followed by people and population. Global inequality came out as the least important driver. The drivers are presented in ascending order of their mean.

The researchers are interested to identify the relationship between Drivers of Sustainable Development and gross monthly turnover. Drivers of Sustainable Development are measured on 5 point scale where 1 is most important driver and 5 is the least important driver. The turnover is measured on 4 different categories. The Spearmen's Rank Correlation and Kendall's Tau correlation is applied and the result is shown in Table 12.

All correlations are found negative indicating that as the gross monthly turnover of the organisation increases, the importance of drivers of sustainable development in the organisation also increases (Because 1 is most important). None of the correlation coefficient was found significant.

\subsection{Most Important Problems}

The descriptive statistics as presented in table 13 shows the most important problem for implementing the sustainability reporting in organisation. The most important factor is lack of legal framework followed by lack of best practice guidance. The factors are presented in ascending order of their mean.

The researcher is interested to identify the relationship between Problems related to sustainability reporting and turnover of an organisation. Major problems for effective sustainability reporting in organisation are measured on 5 point scale where 1 is most important and 5 are the least important measures. The turnover is measured on 4 different categories. The spearmen's rank correlation and Kendall's tau correlation is applied and the result is shown in table 14. All correlations are found positive and significant at $1 \%$ level of significance. Hence it can be concluded that as the gross monthly turnover of an organisation increases, the problems for effective 
sustainability reporting in organisation decreases. So it can be said that as the turnover increases, the organisations become more and more aware regarding the legal framework, best practices and also become more aware regarding the understanding amongst stakeholders and implications at the top management level.

\subsection{Conclusion}

Responding to the adversities that may have been created for the industry participants because of its complexities in implementation, majority of the respondents advocated for a simpler framework which can be accommodated at the SME level. Although there is a sustainability framework developed by GRI but they failed to attract the SME segment of Indian Chemical Industry. Many respondents expressed their inability to understand the complexities of Sustainability Reporting as framed by GRI (Global Reporting Initiative). Majority of the respondents also agreed to accommodate sustainable development as a principle in their mission statement. Most important driver of sustainable development was found to be economy and business followed by people and population. The major problem in implementation of effective sustainability reporting is the absence of legal framework followed by lack of best practice guidance. Although research finds a positive environment and strong industry acceptance of sustainability reporting but lack of awareness about sustainability reporting process as well as absence of a simplified framework of law and practices may deter the growth of sustainability reporting process in Indian Chemical Industry. So the development of a consensus based simplified framework is the need of the hour. A further research can be focused on some innovative initiatives to develop a simplified framework will create some new beginning in the years to come.

\section{References}

Adams, C. A. (2002). Internal Organisational Factors Influencing Corporate Social and Ethical Reporting: Beyond Current Theorising. Accounting, Auditing \& Accountability Journal, 15(2),223-250. Retrieved from http://www.51lunwen.org/UploadFile/org201012101125358808/20101210112535950.pdf

Adams, C. A. (2004). The Ethical, Social and Environmental Reporting-Performance Portrayal Gap. Accounting, Auditing \& Accountability Journal, 17(5), 731-757. http://dx.doi.org/10.1108/09513570410567791

Adams, C. A., \& Patty, M. (2007). Making a Difference:Sustainability Reporting, Accountability and Organisational Change. Accounting, Auditing \& Accountability Journal, 20(3), 382-402. Retrieved from http://www.emeraldinsight.com/doi/abs/10.1108/09513570710748553

Brown, H. S., Martin, J., \& Teodorina, L. (2007). The Rise of Global Reporting Initiative (GRI) as a Case of Institutional Entrepreneurship. Working Paper No 36. Retrieved June 25, 2014, from http://www.hks.harvard.edu/m-rcbg/CSRI/publications/workingpaper_36_brown.pdf

CAG Report No. 9 on PSU. (2007). Environmental Aspect of Sustainability Reporting. Retrieved October 5, 2013, from http://www.cag.gov.in/html/reports/commercial/2007_9reg/chap_4.pdf

CAER (Centre For Australian Ethical Research). (2005). The State of Sustainability Reporting in Australia 2005. Western Australia: Department of Environment and Heritage, Australia.

Cahyandito, M., \& Ebinger, F. (2005). The Effectiveness of Sustainability: Is It Only About the Reporter's Design and Contents. Sustainability Reporting Concepts and Experiences (pp. 27-52). Retrieved from http://pustaka.unpad.ac.id/wp-content/uploads/2009/06/book_icfai_paper_tiger-is_it_only_about_designcon tent_fanifrank.pdf

Carter, C. R., \& Rogers, D. (2008). Logistics Social Responsibility: An Integrative Framework. Journal of Business Logistics, 23(1), 145-180.

Chemistry Leadership Council. (2005). A Vision for the Sustainable Production and Use of Chemicals. London: Forum For the Future.

Cordano, M., Marshall, R. S., \& Silverman, M. (2010). How do Small and Medium Enterprises Go Green? A Study of the Environmental Management Program in Us Wine Industry. Journal of Business Ethics, 92, 463-478. http://10.0.3.239/s10551-009-0168-z

Department of Chemical and Petrochemical Industry. (2008, March). Retrieved August 25, 2013, from http://chemicals.nic.in/chem $1 . h t m$

Department of Chemicals and Petrochemicals. (2013). Annual Report 2012-2013. Retrieved December 25, 2013, from http://chemicals.nic.in/AR_2012-2013_(1-94).pdf

Doane, D., \& MacGillivray, A. (2001, March). Economic Sustainability: The Business of Staying in Business. Retrieved September 29, 2013, from http://projectsigma.co.uk/RnDStreams/RD_economic_sustain.pdf 
Elkington, J. (1997). Cannibals with Forks, Triple Bottom Line of 21st Century Business. Oxford, Capstone Publishing.

FICCI \& TSMG. (2010, October). India Chem 2010:Sustaining the India Advantage. Retrieved January 14, 2012, from http://www.rolandberger.com/media/pdf/Roland_Berger_India_Chem_20101109.pdf

Fiksel, J., Low, J., \& Thomas, J. (2004, June). Linking Sustainability to Shareholder Value. Retrieved September 29, 2013, from http://www.eco-nomics.com/images/Linking_Sustainability_to_Value.pdf

GRI (Global Reporting Initiative). (2002, September). Sustainability Reporting Guidelines. Retrieved January 23, 2013, from http://www.epeat.net/documents/EPEATreferences/GRIguidelines.pdf

Kolk, A. (2004). A Decade of Sustainability Reporting: Developments and Significance. International Journal of Environment and Sustainable Development, 3(1), 51-64. http://dare.uva.nl/document/2/25817

Koski, C., \& May, P. J. (2006). Interest and Implementation: Fostering Voluntary Regulatory Action. Journal of Public Administration: Research and Theory, 16, 329-340. http://10.0.4.69/jopart/mui048

KPMG. (2007). Accelerating Growth in Gujarat: A discussion Note. KPMG International, India.

KPMG Chemtech Foundation. (2013, January 20). The Indian Chemical Industry -New Direction New Hope. Retrieved July 7, 2013, from http://www.kpmg.com/in/en/issuesandinsights/articlespublications/pages/ theindianchemicalindustry-newdirections,newhope.aspx

Larrinaga, G. C.-G., \& Paez-Sandubete, J. (2001). The Role of Environmental Accountingin organizational Change: An Exploration of Spanish Companies. Accounting, Auditing \& Accountability Journal, 14(2), 213-239.

O'Dwyer, B. (2002). Managerial Perceptions of Corporate Social Disclosure: An Irish Story. Accounting, Auditing \& Accountability Journal, 15(3), 406-436.

Planning Commission. (2010, November 12). Working Group on Indian Chemical Industry. Retrieved January 25, 2013, from http://ebookbrowsee.net/wg11-chemical-doc-d27381717

Pleon, B. V. (2005, September). Accounting for Good:The Global Stakeholder Report. Retrieved February 23, 2013, from http://www.jussemper.org/Newsletters/Resources/Pleon_GSR05_en.pdf

Reddy, S. (2005). Sustainability Reporting in Asia. In S. Reddy (Ed.), Sustainability Reporting Concepts and Experiences (pp. 122-133). The ICFAI University Press, Hyderabad.

Schaltegger, S., Buritt, R., \& Petersen, H. (2003). An Introduction to Corporate Environmental Management: Striving for Sustainability. Sheffield, Greenleaf Publishing.

Shekharan, N. (2012). Trends in Sustainability Reporting in India. Retrieved July 7, 2013, from $\mathrm{http} / / / \mathrm{www} . e m e r g e n t-v e n t u r e s . c o m /$ insights/trends-in-sustainability-reporting-148.html\&type=insights

TSMG (Tata Strategic Management Group). (2012, September). Emerging India Sustainable Growth of Chemical Sector. Retrieved April 28, 2013, from http://www.ficci.com/spdocument/20171/ Knowledge\%20Paper.pdf

UNDP. (2013). Human Development Report 2013. Retrieved April 5, 2013, from http:/hdr.undp.org/ sites/default/files/reports/14/hdr2013_en_complete.pdf

Wensen, K., Wijnand, B., Johanna, K., \& Jutta, K. (2011). The State of Play in Sustainability Reporting in the European Union.

World Business Council Of Sustainable Development (WBCSD). (2002). Sustainable Development Reporting: Striking the Balance. Geneva.

World Commission on Environment and Development (WCED). (1987).Our Common Future. Oxford, Oxford University Press.

Wright, R. T. (2007). Environmental Science Toward a Sustainable Future (9th ed.). New Delhi, Prentice Hall of India.

\section{Copyrights}

Copyright for this article is retained by the author(s), with first publication rights granted to the journal.

This is an open-access article distributed under the terms and conditions of the Creative Commons Attribution license (http://creativecommons.org/licenses/by/3.0/). 


\section{Appendix}

Table 3A: Category wise knowledge about sustainability reporting aspects Does your company "Know About Sustainability Reparting Aspects"? Cross tabu lation

\begin{tabular}{|c|c|c|c|c|c|}
\hline & & & \multicolumn{2}{|c|}{$\begin{array}{l}\text { Does your company } \\
\text { know about } \\
\text { Sustainability Repporting } \\
\text { Aspects? }\end{array}$} & \multirow[t]{2}{*}{ Total } \\
\hline & & & Yes & No & \\
\hline \multirow{18}{*}{ Category } & \multirow{3}{*}{$\begin{array}{l}\text { Peirochemi } \\
\text { cals }\end{array}$} & Count & 18 & 1 & 19 \\
\hline & & $\begin{array}{l}\text { Expected } \\
\text { Count }\end{array}$ & 4 & 15 & 19 \\
\hline & & $\begin{array}{l}\text { \%6 within } \\
\text { Category }\end{array}$ & $94.70 \%$ & $5.30 \%$ & $100.00 \%$ \\
\hline & \multirow{4}{*}{$\begin{array}{l}\text { Fertilizer } \\
\& \\
\text { Pesticides }\end{array}$} & Coumt & 18 & 16 & 34 \\
\hline & & $\begin{array}{l}\text { Expected } \\
\text { Count }\end{array}$ & 7.1 & 269 & 34 \\
\hline & & $\begin{array}{l}\text { 96 within } \\
\text { Category }\end{array}$ & $52.90 \%$ & $47.10 \%$ & $100.00 \%$ \\
\hline & & Coumt & 8 & 44 & 52 \\
\hline & \multirow[t]{3}{*}{ Pharma } & $\begin{array}{l}\text { Expected } \\
\text { Count }\end{array}$ & 10.9 & 41.1 & 52 \\
\hline & & $\begin{array}{l}\text { \% within } \\
\text { Category }\end{array}$ & $15.40 \%$ & $84.60 \%$ & $100.00 \%$ \\
\hline & & Count & 38 & 200 & 238 \\
\hline & \multirow[t]{3}{*}{$\begin{array}{l}\text { Dyes \& } \\
\text { Pigments }\end{array}$} & $\begin{array}{l}\text { Expected } \\
\text { Coumt }\end{array}$ & 49.8 & 188.2 & 238 \\
\hline & & $\begin{array}{l}\text { \% within } \\
\text { Category }\end{array}$ & $16.00 \%$ & $84.00 \%$ & $100.00 \%$ \\
\hline & & Count & 13 & 64 & 77 \\
\hline & \multirow[t]{2}{*}{ Organic } & $\begin{array}{l}\text { Expected } \\
\text { Coumt }\end{array}$ & 16.1 & 60.9 & 77 \\
\hline & & $\begin{array}{l}96 \text { within } \\
\text { Category }\end{array}$ & $16.90 \%$ & $83.10 \%$ & $100.00 \%$ \\
\hline & \multirow{3}{*}{ Inorganic } & Count & 13 & 83 & 96 \\
\hline & & $\begin{array}{l}\text { Expected } \\
\text { Coumt }\end{array}$ & 20.1 & 759 & 96 \\
\hline & & $\begin{array}{l}\text { 96 within } \\
\text { Category }\end{array}$ & $13.50 \%$ & $86.50 \%$ & $100.00 \%$ \\
\hline \multirow{3}{*}{ Total } & & Coumt & 108 & 408 & 516 \\
\hline & & $\begin{array}{l}\text { Expected } \\
\text { Count }\end{array}$ & 108 & 408 & 516 \\
\hline & & $\begin{array}{l}\text { \% within } \\
\text { Category }\end{array}$ & $20.90 \%$ & $79.10 \%$ & $100.00 \%$ \\
\hline
\end{tabular}

Table 3B: Chi-Square Tests and Symmetric Measures

\begin{tabular}{lcccc}
\hline & Value & Df & $\begin{array}{c}\text { Asymp. Sig. } \\
\text { (2-sided) }\end{array}$ \\
\hline Pearsan Chi-Square & $92.031^{2}$ & 5 & 0 \\
Symmetric Measures & Value & & Approx. Sig. \\
\hline Nominal by Naminal & 0.422 & 0 \\
& 0.422 & 0
\end{tabular}

Table 5A: Category wise perception about Sustainability Reporting as a part of framework of Corporate Governance process Category * Should Sustainability Reporting be a part of framework of Corporate Governance process? Crosstabulation

\begin{tabular}{|c|c|c|c|c|c|}
\hline & & & \multicolumn{2}{|c|}{$\begin{array}{l}\text { Should Sustainability } \\
\text { Reporting be a part of } \\
\text { framework of Corporate } \\
\text { Governance process? }\end{array}$} & \multirow[t]{2}{*}{ Total } \\
\hline & & & Yes & No & \\
\hline \multirow{18}{*}{ Category } & \multirow{4}{*}{$\begin{array}{l}\text { Petroc chemi } \\
\text { cals }\end{array}$} & Count & 14 & 5 & 19 \\
\hline & & $\begin{array}{l}\text { Expected } \\
\text { Count }\end{array}$ & 14.1 & 49 & 19 \\
\hline & & $\begin{array}{l}\% \text { within } \\
\text { Category }\end{array}$ & $73.70 \%$ & $26.30 \%$ & $100.00 \%$ \\
\hline & & Count & 29 & 5 & 34 \\
\hline & \multirow{3}{*}{$\begin{array}{l}\text { Fertilizer \& } \\
\text { Pesticides }\end{array}$} & $\begin{array}{l}\text { Expected } \\
\text { Coumt }\end{array}$ & 25.2 & 8.8 & 34 \\
\hline & & $\begin{array}{l}96 \text { within } \\
\text { Category }\end{array}$ & $85.30 \%$ & $14.70 \%$ & $100.00 \%$ \\
\hline & & Count & 44 & 8 & 52 \\
\hline & \multirow[t]{3}{*}{ Pharma } & $\begin{array}{l}\text { Expected } \\
\text { Count }\end{array}$ & 38.6 & 13.4 & 52 \\
\hline & & $\begin{array}{l}\% \text { within } \\
\text { Category }\end{array}$ & $84.60 \%$ & $15.40 \%$ & $100.00 \%$ \\
\hline & & Count & 151 & 87 & 238 \\
\hline & \multirow{3}{*}{$\begin{array}{l}\text { Dyes \& } \\
\text { Pigments }\end{array}$} & $\begin{array}{l}\text { Expected } \\
\text { Count }\end{array}$ & 176.7 & 61.3 & 238 \\
\hline & & $\begin{array}{l}\text { \% within } \\
\text { Category }\end{array}$ & 63.4096 & $36.60 \%$ & $100.00 \%$ \\
\hline & & Count & 63 & 14 & 77 \\
\hline & \multirow[t]{3}{*}{ Organic } & $\begin{array}{l}\text { Expected } \\
\text { Coumt }\end{array}$ & 57.2 & 19.8 & 77 \\
\hline & & $\begin{array}{l}\% \text { within } \\
\text { Category }\end{array}$ & $81.80 \%$ & $18.20 \%$ & $100.00 \%$ \\
\hline & & Count & 82 & 14 & 96 \\
\hline & \multirow{2}{*}{ Inorganic } & Expected & 71.3 & 24.7 & 96 \\
\hline & & $\begin{array}{l}\text { \% within } \\
\text { Category }\end{array}$ & $85.40 \%$ & $14.60 \%$ & $100.00 \%$ \\
\hline \multirow{3}{*}{ Total } & & Count & 383 & 133 & 516 \\
\hline & & $\begin{array}{l}\text { Expected } \\
\text { Count }\end{array}$ & 383 & 133 & 516 \\
\hline & & $\begin{array}{l}\text { within } \\
\text { Category }\end{array}$ & $74.20 \%$ & $25.80 \%$ & $100.00 \%$ \\
\hline
\end{tabular}

Table 4A: Category wise belief about Sustainability Reporting aspects Category * Does your company believe on sustaunability roporting? Crosstabulation

\begin{tabular}{|c|c|c|c|c|c|}
\hline & & & $\begin{array}{r}\text { Does yo } \\
\text { bolieve on } \\
\text { repp }\end{array}$ & $\begin{array}{l}\text { ompanyy } \\
\text { tamability } \\
\text { ng? }\end{array}$ & Total \\
\hline & & & Yes & No & \\
\hline & & Count & 17 & 2 & 19 \\
\hline & Petrachemi & $\begin{array}{l}\text { Expected } \\
\text { Count }\end{array}$ & 17.4 & 1.6 & 19 \\
\hline & & $\begin{array}{l}96 \text { within } \\
\text { Categrony }\end{array}$ & $89.50 \%$ & $10.50 \%$ & $100.00 \%$ \\
\hline & & Coumt & 32 & 2 & 34 \\
\hline & $\begin{array}{l}\text { Fertilizer } \\
\text { de }\end{array}$ & $\begin{array}{l}\text { Expected } \\
\text { Coumt }\end{array}$ & 31.1 & 2.9 & 34 \\
\hline & Pesticides & $\begin{array}{l}96 \text { within } \\
\text { Category }\end{array}$ & $94.10 \%$ & $5.90 \%$ & $100.00 \%$ \\
\hline & & Count & 51 & 1 & 52 \\
\hline & Pharma & $\begin{array}{l}\text { Expected } \\
\text { Count }\end{array}$ & 47.6 & 4.4 & 52 \\
\hline & & $\begin{array}{l}96 \text { within } \\
\text { Category }\end{array}$ & $98.10 \%$ & $1.90 \%$ & $100.00 \%$ \\
\hline Category & & Coumt & 207 & 31 & 238 \\
\hline & $\begin{array}{l}\text { Dyes \& } \\
\text { Pigments }\end{array}$ & $\begin{array}{l}\text { Expected } \\
\text { Count }\end{array}$ & 217.7 & 20.3 & 238 \\
\hline & & $\begin{array}{l}\text { 96 within } \\
\text { Category }\end{array}$ & $87.00 \%$ & $13.00 \%$ & $100.00 \%$ \\
\hline & & Count & 70 & 7 & 77 \\
\hline & Organic & $\begin{array}{l}\text { Expected } \\
\text { Coumt }\end{array}$ & $70-4$ & 6.6 & 77 \\
\hline & & $\begin{array}{l}\text { 96 within } \\
\text { Category }\end{array}$ & $90.90 \%$ & $9.10 \%$ & $100.00 \%$ \\
\hline & & Coumt & 95 & 1 & 96 \\
\hline & Inorganic & $\begin{array}{l}\text { Expected } \\
\text { Coumt }\end{array}$ & 87.8 & 8.2 & 96 \\
\hline & & $\begin{array}{l}\text { \% within } \\
\text { Categony }\end{array}$ & $99.00 \%$ & $1.00 \%$ & $100.00 \%$ \\
\hline & & Coumt & 472 & 44 & 516 \\
\hline Total & & Expected & 472 & 44 & 516 \\
\hline & & 96 within & $91.50 \%$ & $8.50 \%$ & $100.00 \%$ \\
\hline
\end{tabular}

Table 4B: Chi-Square Tests and Symmetric measures

\begin{tabular}{lc|ccc}
\hline & Value & Df & $\begin{array}{c}\text { Asymm. Sig. } \\
(2-\text { sided })\end{array}$ \\
\hline $\begin{array}{l}\text { Pearson Chi-Square } \\
\text { Symmetric Measures }\end{array}$ & $16.411^{*}$ & 5 & 0.006 \\
\hline Nominal by Phi & 0.178 & & 0.006 \\
Nominal Cramer's V & 0.178 & & 0.006
\end{tabular}

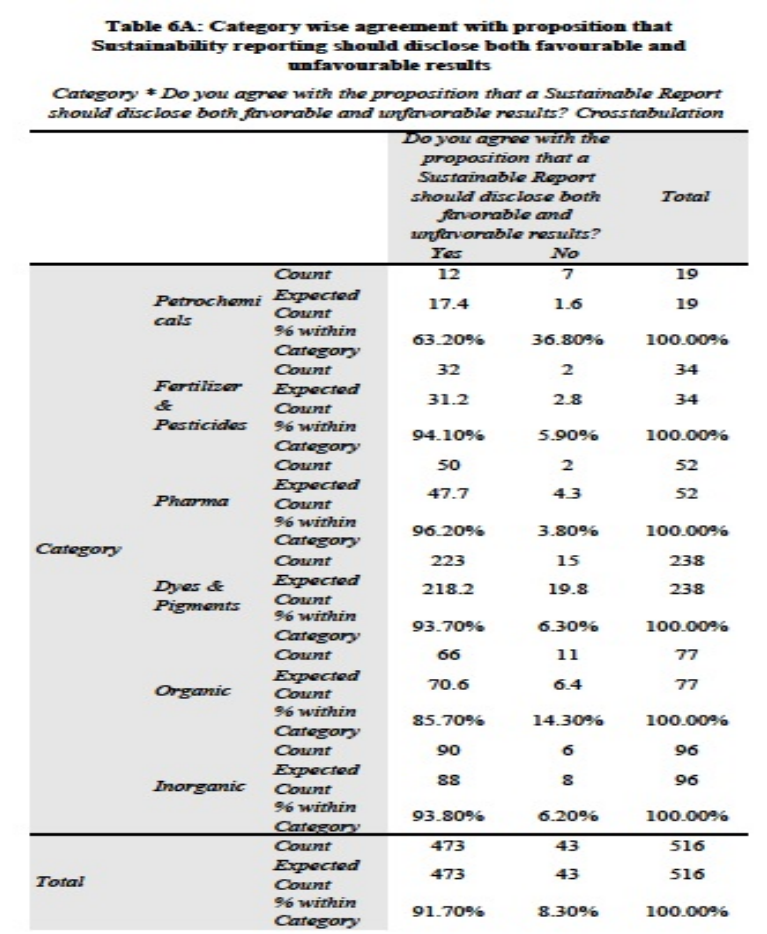




\begin{tabular}{|c|c|c|c|}
\hline & Value & Df & $\begin{array}{c}\text { Asymm. Sig } \\
\text { (2-sided) }\end{array}$ \\
\hline Pearson Chi-Square & $2 \mathrm{R} .176 \mathrm{a}$ & 5 & 0.000 \\
\hline Symmetric Measures & & & Approx. Sig \\
\hline $\begin{array}{l}\text { Nominal by Phi } \\
\text { Nominal Cramer's V }\end{array}$ & $\begin{array}{l}0.234 \\
0.234\end{array}$ & & $\begin{array}{l}0.000 \\
0.000\end{array}$ \\
\hline
\end{tabular}

\begin{tabular}{|c|c|c|c|c|c|}
\hline \multicolumn{6}{|c|}{$\begin{array}{l}\text { Categony * Do yout consider issues nolating to Sustainable Development } \\
\text { and Roporting are relevant in the Indtian context? Cross tabulation }\end{array}$} \\
\hline & & & \multicolumn{2}{|c|}{$\begin{array}{l}\text { Do your consider issthes } \\
\text { relating to Sustatinabile } \\
\text { Development and } \\
\text { Repporting are relevant } \\
\text { in the Inditan context? }\end{array}$} & \multirow[t]{2}{*}{ Total } \\
\hline & & & Yes & & \\
\hline \multirow{18}{*}{ Category } & \multirow{4}{*}{$\begin{array}{l}\text { Petrochemi } \\
\text { cals }\end{array}$} & Count & 10 & 9 & 19 \\
\hline & & Expected & 16.4 & 2.6 & 19 \\
\hline & & $\begin{array}{l}\text { \%o within } \\
\text { Categoory }\end{array}$ & $52.60 \%$ & $47.40 \%$ & $100.00 \%$ \\
\hline & & Coumt & 32 & 2 & 34 \\
\hline & \multirow{4}{*}{$\begin{array}{l}\text { Fertilizer \& } \\
\text { Pesticides }\end{array}$} & $\begin{array}{l}\text { Expected } \\
\text { Count }\end{array}$ & 29.4 & 4.6 & 34 \\
\hline & & $\begin{array}{l}\text { \% within } \\
\text { Category }\end{array}$ & $94.10 \%$ & $5.90 \%$ & 100.009 \\
\hline & & Count & 47 & 5 & 52 \\
\hline & & $\begin{array}{l}\text { Expected } \\
\text { Coumt }\end{array}$ & 44.9 & 7.1 & 52 \\
\hline & \multirow{2}{*}{ Pharma } & $\begin{array}{l}\text { \%6 within } \\
\text { Category }\end{array}$ & $90.40 \%$ & $9.60 \%$ & $100.00 \%$ \\
\hline & & Count & 199 & 39 & 238 \\
\hline & \multirow{3}{*}{$\begin{array}{l}\text { Dyes \& } \\
\text { Pigments }\end{array}$} & $\begin{array}{l}\text { Expected } \\
\text { Count }\end{array}$ & 205.7 & 32.3 & 238 \\
\hline & & \% within & $83.60 \%$ & $16.40 \%$ & $100.00 \%$ \\
\hline & & Coumt & 64 & 13 & 77 \\
\hline & \multirow[t]{3}{*}{ Organic } & $\begin{array}{l}\text { Expected } \\
\text { Coumt }\end{array}$ & 66.6 & 10.4 & 77 \\
\hline & & $\begin{array}{l}\text { \% within } \\
\text { Category }\end{array}$ & $83.10 \%$ & $16.90 \%$ & $100.00 \%$ \\
\hline & & Count & 94 & 2 & 96 \\
\hline & \multirow{2}{*}{ Inorganic } & Expected & 83 & 13 & 96 \\
\hline & & \%o within & 97.9096 & $2.10 \%$ & $100.00 \%$ \\
\hline \multirow{3}{*}{\multicolumn{2}{|c|}{ Total }} & Coumt & 446 & 70 & 516 \\
\hline & & Expected & 446 & 70 & 516 \\
\hline & & 96 within & 86.4096 & $13.60 \%$ & $100.00 \%$ \\
\hline
\end{tabular}

\begin{tabular}{|c|c|c|c|}
\hline \multicolumn{4}{|c|}{ Ranks } \\
\hline & Category & $\mathbf{N}$ & Mean Rank \\
\hline \multirow{7}{*}{ Factor 1} & Petrochemicals & 19 & 238.47 \\
\hline & Fertilizer \& Pesticides & 28 & 261.82 \\
\hline & Pharma & 44 & 252.95 \\
\hline & Dyes \& Pigments & 210 & 194.47 \\
\hline & Organic & 68 & 204.6 \\
\hline & Inorgamic & 46 & 186.46 \\
\hline & Total & 415 & \\
\hline \multirow{7}{*}{ Factor 2} & Petrochemicals & 19 & 238.32 \\
\hline & Fertilizer \& Pesticides & 28 & 239.21 \\
\hline & Pharma & 44 & 149.86 \\
\hline & Dyes \& Pigments & 210 & 212.94 \\
\hline & Organic & 68 & 212.83 \\
\hline & Inorganic & 46 & 202.41 \\
\hline & Total & 415 & \\
\hline \multirow{7}{*}{ Factor 3} & Petrochemicals & 19 & 236.68 \\
\hline & Fertilizer \& Pesticides & 28 & 252.29 \\
\hline & Pharma & 44 & 147.27 \\
\hline & Dyes \& Pigments & 210 & 219.93 \\
\hline & Organic & 68 & 216.15 \\
\hline & Inorganic & 46 & 160.78 \\
\hline & Total & 415 & \\
\hline \multirow{7}{*}{ Factor 4} & Petrochemicals & 19 & 144.63 \\
\hline & Fertilizer \& Pesticides & 28 & 213.79 \\
\hline & Pharma & 44 & 205.09 \\
\hline & Dyes \& Pigments & 210 & 212.26 \\
\hline & Organic & 68 & 218.73 \\
\hline & Inorganic & 46 & 198.13 \\
\hline & Total & 415 & \\
\hline \multirow{7}{*}{ Factor 5} & Petrochemicals & 19 & 326.95 \\
\hline & Fertilizer \& Pesticides & 28 & 217.5 \\
\hline & Pharma & 44 & 209.18 \\
\hline & Dyes \& Pigments & 210 & 186.43 \\
\hline & Organic & 68 & 213.23 \\
\hline & Inorganic & 46 & 242.72 \\
\hline & Total & 415 & \\
\hline
\end{tabular}

\begin{tabular}{lcccc}
\multicolumn{4}{c}{ Table 6B: Chi-Square Tests and Symmetric measures } \\
\hline & Value & Df & $\begin{array}{c}\text { Asymp. Sig } \\
\text { (2-sided) }\end{array}$ \\
\hline Pearson Chi-Square & 27.255 & 5 & 0.000 \\
\multicolumn{1}{c}{ Symmetric Measures } & & & Approx. Sig \\
\hline Nominal by Phi & 0.23 & & 0.000 \\
Nominal Cramer's V & 0.23 & & 0.000
\end{tabular}

Table 7B: Chi-Square Tests and Symmetric measures

\begin{tabular}{|c|c|c|c|}
\hline & Value & Df & $\begin{array}{c}\text { Asymm. Sig } \\
\text { (2-sided) }\end{array}$ \\
\hline Pearson Chi-Square & \multirow[t]{2}{*}{34.0518} & \multirow[t]{2}{*}{5} & 0.000 \\
\hline Synmetric Measures & & & Approx. Sig. \\
\hline Nominal by Phi & 0.257 & & 0.000 \\
\hline Nominal Cramer's V & 0.257 & & 0.000 \\
\hline
\end{tabular}

Table 8: Tests of Normality

\begin{tabular}{|c|c|c|c|c|c|c|}
\hline & \multicolumn{2}{|c|}{ Kolmogorov-Snimov" } & \multicolumn{3}{|c|}{ Shapiro-Wilk } & \multirow[b]{2}{*}{ Sig. } \\
\hline & Statistic & Df & Sig. & Statistic & Df & \\
\hline$\overline{\text { Factor } 1}$ & 0.141 & 419 & 0 & 0.91 & 419 & 0 \\
\hline Factor 2 & 0.168 & 419 & 0 & 0.856 & 419 & 0 \\
\hline Factor 3 & 0.151 & 419 & 0 & 0.839 & 419 & 0 \\
\hline Factor 4 & 0.108 & 419 & 0 & 0.946 & 419 & 0 \\
\hline Factor 5 & 0.236 & 419 & 0 & 0.712 & 419 & 0 \\
\hline
\end{tabular}

a. Lilliefors Significance Correction

\begin{tabular}{lccccc}
\multicolumn{7}{c}{ Table 9B: Test Statistics, } \\
\hline \multicolumn{7}{c}{ Factor 1 } & Factor 2 & Factor 3 & Factor 4 & Factor 5 \\
\hline Chi-Square & 17.276 & 14.029 & 25.731 & 6.522 & 29.676 \\
Df & 5 & 5 & 5 & 5 & 5 \\
Asymp. & 0.004 & 0.015 & 0 & 0.259 & 0 \\
\hline Sig. & & & & &
\end{tabular}

C. Eraskal Wallis Test

b. Growping Variable: Category

Table 10 A- Report of Kruskal Wallis test and ranks

\begin{tabular}{|c|c|c|c|}
\hline & Gross monthly turnover - In Lakhs & $\mathbf{N}$ & Mean Rank \\
\hline & $5-25$ & 27 & 226.91 \\
\hline & $25-500$ & 233 & 196.29 \\
\hline \multirow{5}{*}{ Factor 1} & $500-1000$ & 74 & 174.29 \\
\hline & More than 1000 & 85 & 273.31 \\
\hline & Total & 419 & \\
\hline & $5-25$ & 27 & 256.13 \\
\hline & $25-500$ & 233 & 203.25 \\
\hline \multirow[t]{5}{*}{ Factor 2} & $500-1000$ & 74 & 219.44 \\
\hline & More than 1000 & 85 & 205.64 \\
\hline & Total & 419 & \\
\hline & $5-25$ & 27 & 274.46 \\
\hline & $25-500$ & 233 & 190.12 \\
\hline \multirow[t]{5}{*}{ Factor 3} & $500-1000$ & 74 & 221.95 \\
\hline & More than 1000 & 85 & 233.6 \\
\hline & Total & 419 & \\
\hline & $5-25$ & 27 & 238.35 \\
\hline & $25-500$ & 233 & 206.72 \\
\hline \multirow[t]{5}{*}{ Factor 4} & $500-1000$ & 74 & 204.82 \\
\hline & More than 1000 & 85 & 214.51 \\
\hline & Total & 419 & \\
\hline & $5-25$ & 27 & 142.5 \\
\hline & $25-500$ & 233 & 211.1 \\
\hline \multirow[t]{3}{*}{ Factor 5} & $500-1000$ & 74 & 215.2 \\
\hline & More than 1000 & 85 & 223.89 \\
\hline & Total & 419 & \\
\hline
\end{tabular}

\begin{tabular}{lccccc}
\multicolumn{7}{c}{ Table 10 B: Test Statistics, } \\
\hline \multicolumn{7}{c}{ Factor 1 } & Factor 2 & Factor 3 & Factor 4 & Factor 5 \\
\hline Chi-Square & 33.214 & 5.208 & 17.896 & 1.907 & 9.674 \\
Df & 3 & 3 & 3 & 3 & 3 \\
Asymp. & 0 & 0.157 & 0 & 0.592 & 0.022 \\
Sig. & 0 & & & &
\end{tabular}

b. Grouping Variable: Gross monthly turnover - In Lakhs 


\begin{tabular}{cccccc}
\multicolumn{8}{c}{ Tablell: Descriptive statistics of drivers of sustainability reporting } \\
\hline Drivers & N & Minimum & Marimum & Mean & $\begin{array}{c}\text { Std } \\
\text { Deviation }\end{array}$ \\
\hline Economics\& business & 520 & 1 & 5 & 1.4192 & 0.70861 \\
People and population & 520 & 1 & 5 & 1.4288 & 0.75439 \\
Enabling technology & 520 & 1 & 5 & 1.45 & 0.77373 \\
Regulation & 520 & 1 & 4 & 1.4635 & 0.72034 \\
Euviroumental crisis & 520 & 1 & 5 & 1.4981 & 0.81649 \\
Global inequality & 520 & 1 & 5 & 1.5904 & 0.88419 \\
\hline
\end{tabular}

Table 12: Result of Spearman rank correlation for drivers of sustainable development

\begin{tabular}{llc}
\hline \multicolumn{2}{c}{ Category : Gross monthly turnover - In Lakhs } \\
\hline Economic \& business & Pearson Correlation & $0-.011$ \\
& Sig. (2-tailed) & 0.836 \\
People and population & Pearson Correlation & -0.077 \\
& Sig. (2-tailed) & 0.138 \\
Enabling technology & Pearson Correlation & -0.053 \\
& Sig (2-tailed) & 0.313 \\
Environmental crisis & Pearson Correlation & -0.023 \\
& Sig (2-tailed) & 0.659 \\
Global inequality & Pearson Correlation & -0.041 \\
& Sig (2-tailed) & 0.434 \\
Regulation & Pearson Correlation & -0.07 \\
& Sig. (2-tailed) & 0.182 \\
\hline
\end{tabular}

*.. Correlation is significant at the 0.01 level (2-tailed).

\section{Table 13: Descriptive Statistics Related to Different Aspect of Problem}

\begin{tabular}{lccccc}
\multicolumn{4}{c}{ Table 13: Descriptive Statistics Related to Different Aspect of Problem } \\
\hline \multicolumn{1}{c}{ Factors } & Min. & Mar. & Mean & Std Dev \\
\hline Lack of legal framework & 1 & 5 & 1.4635 & 0.91583 \\
Lack of best practice guidance & 1 & 5 & 1.4769 & 0.9694 \\
$\begin{array}{l}\text { Lack of leadership and innovation in Sustainable Development \& } \\
\text { Reporting }\end{array}$ & 1 & 5 & 1.5096 & 0.93317 \\
$\begin{array}{l}\text { Absence of extermal motivation and enforcement mechanism } \\
\text { Lack of awareness and understanding amongst stakeholders }\end{array}$ & 1 & 5 & 1.5154 & 0.97747 \\
$\begin{array}{l}\text { Lack of awareness \& understanding of implications at the top } \\
\text { management level }\end{array}$ & 1 & 5 & 1.5904 & 1.05691 \\
\hline
\end{tabular}

Table 14A: Rank Correlation report on the problems of Sustainability Reporting

\begin{tabular}{|c|c|c|c|c|c|c|c|c|c|}
\hline & & & $\begin{array}{l}\text { Gross } \\
\text { Turn over. } \\
\text { In Lalte }\end{array}$ & $\begin{array}{l}\text { Lachof legal } \\
\text { frume mork }\end{array}$ & $\begin{array}{l}\text { Lach of best } \\
\text { practice } \\
\text { guidance }\end{array}$ & 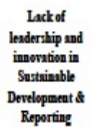 & $\begin{array}{l}\text { Abreace of } \\
\text { erternal } \\
\text { motivation and } \\
\text { emforcemeat } \\
\text { mechanitum }\end{array}$ & 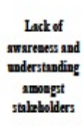 & 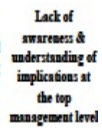 \\
\hline \multirow{21}{*}{$\begin{array}{c}\text { Tendalls } \\
\text { tam_b }\end{array}$} & \multirow{3}{*}{$\begin{array}{l}\text { Gross monathy } \\
\text { turnover-In } \\
\text { Laths }\end{array}$} & $\begin{array}{l}\text { Conralstion } \\
\text { Coesficiant }\end{array}$ & 1 & $.136^{\prime \prime}$ & $.169^{\prime \prime}$ & $.143^{\prime \prime}$ & $.153 "$ & $.124^{\prime \prime}$ & $.123^{\prime \prime}$ \\
\hline & & 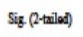 & . & 0.001 & 0 & 0 & 0 & 0.002 & 0.002 \\
\hline & & $\mathrm{N}$ & 520 & 520 & 520 & 520 & 520 & 520 & 520 \\
\hline & \multirow{3}{*}{$\begin{array}{l}\text { Lach of bogal } \\
\text { frameroun }\end{array}$} & $\begin{array}{l}\text { Coneralsion } \\
\text { Coesficant }\end{array}$ & $.136^{\prime \prime}$ & 1 & $.824^{\prime \prime}$ & $.691^{\prime \prime}$ & $.712^{\prime \prime}$ & $.654^{\prime \prime}$ & $.668 "$ \\
\hline & & $\operatorname{Sig}(2-2+a i d a t)$ & 0.001 & . & 0 & 0 & 0 & 0 & 0 \\
\hline & & $\mathrm{N}$ & 520 & 520 & 520 & 520 & 520 & 520 & 520 \\
\hline & \multirow{3}{*}{$\begin{array}{l}\text { Lack of bust } \\
\text { pratico guidancec }\end{array}$} & $\begin{array}{l}\text { Candartion } \\
\text { Cosefficont }\end{array}$ & $.169^{\prime \prime}$ & $.824^{\prime \prime}$ & 1 & .74 & $.79 "$ &.$m "$ & $.773^{\prime \prime}$ \\
\hline & & $\operatorname{Sig}(2+$ tallatat) & 0 & 0 & & 0 & 0 & 0 & 0 \\
\hline & & $\mathrm{N}$ & 520 & 520 & 520 & 520 & 520 & 520 & 520 \\
\hline & \multirow{2}{*}{ 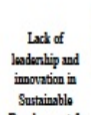 } & $\begin{array}{l}\text { Coneralsion } \\
\text { Coesfcicont }\end{array}$ & $.143^{\prime \prime}$ & $.691^{\prime \prime}$ & $.774^{\prime \prime}$ & 1 & $.795^{\prime \prime}$ & $.713^{\prime \prime}$ & $.748^{\prime \prime}$ \\
\hline & & Sig (2-tallad) & 0 & 0 & 0 & . & 0 & 0 & 0 \\
\hline & $\begin{array}{c}\text { Denvolopeseat is to } \\
\text { Reporting }\end{array}$ & $\mathrm{N}$ & 520 & 520 & 520 & 520 & 520 & 520 & 520 \\
\hline & \multirow{3}{*}{ 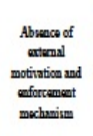 } & $\begin{array}{l}\text { Corralntion } \\
\text { Coesficiant }\end{array}$ & $.133^{\prime \prime}$ & $.712^{\prime \prime}$ & $.779^{\prime \prime}$ & . $795 "$ & 1 & $.753 "$ & $.733^{\prime \prime}$ \\
\hline & & Sig (2-talled) & 0 & 0 & 0 & 0 & . & 0 & 0 \\
\hline & & $\mathrm{N}$ & 520 & 520 & 520 & 520 & 520 & 520 & 520 \\
\hline & \multirow{3}{*}{$\begin{array}{l}\text { Lack of } \\
\text { zunreous and } \\
\text { umdertanding } \\
\text { among } \\
\text { stablobolder }\end{array}$} & $\begin{array}{l}\text { Conrelation } \\
\text { Coesficiant }\end{array}$ & $.124^{\prime \prime}$ & $.654^{\prime \prime}$ & $.722^{\prime \prime}$ & $.713^{\prime \prime}$ & $.733^{\prime \prime}$ & 1 & $.848^{\prime \prime}$ \\
\hline & & 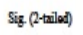 & 0.002 & 0 & 0 & 0 & 0 & . & 0 \\
\hline & & $\mathrm{N}$ & 520 & 520 & 520 & 520 & 520 & 520 & 520 \\
\hline & \multirow{3}{*}{ 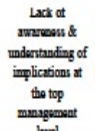 } & $\begin{array}{l}\text { Condalsion } \\
\text { Coesficiont }\end{array}$ & $.123^{"}$ & $.668 "$ & $.773^{\prime \prime}$ & $.748^{\prime \prime}$ & $.733^{\prime \prime}$ & $.848^{\prime \prime}$ & 1 \\
\hline & & $\operatorname{Sig}(2-$ tallated) & 0.002 & 0 & 0 & 0 & 0 & 0 & \\
\hline & & $\mathrm{N}$ & 520 & 520 & 520 & 520 & 520 & 520 & 520 \\
\hline
\end{tabular}

Table 14B: Rank Correlation report on the problems of Sustainability reporting

\begin{tabular}{|c|c|c|c|c|c|c|c|c|c|}
\hline & & & $\begin{array}{l}\text { Gross Tann } \\
\text { over - In } \\
\text { Lalthe }\end{array}$ & $\begin{array}{l}\text { Lack of legal } \\
\text { frrme work }\end{array}$ & $\begin{array}{l}\text { Lack of best } \\
\text { prascice } \\
\text { guidance }\end{array}$ & 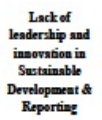 & $\begin{array}{l}\text { Absence of } \\
\text { erternal } \\
\text { motivition and } \\
\text { eufforcement } \\
\text { mechanism }\end{array}$ & $\begin{array}{l}\text { Lack of } \\
\text { swareness and } \\
\text { understandiag } \\
\text { amogert } \\
\text { stalebolders }\end{array}$ & $\begin{array}{c}\text { Lackef } \\
\text { smaresess a } \\
\text { understandiag of } \\
\text { implicatious at } \\
\text { the top } \\
\text { managemeat level }\end{array}$ \\
\hline \multirow{21}{*}{$\begin{array}{l}\text { Sparmmon' } \\
\text { tho }\end{array}$} & \multirow{4}{*}{ 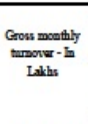 } & $\begin{array}{l}\text { Comalalsion } \\
\text { Cosfficiant }\end{array}$ & 1 & $.148^{\prime \prime}$ & $.185^{\prime \prime}$ & $.157^{\prime \prime}$ & $.169^{\prime \prime}$ & $.137^{\prime \prime}$ & $.136^{\prime \prime}$ \\
\hline & & Sig (2-tailod) & . & 0.001 & 0 & 0 & 0 & 0.002 & 0.002 \\
\hline & & $\mathrm{N}$ & 520 & 520 & 520 & 520 & 520 & 520 & 520 \\
\hline & & $\begin{array}{l}\text { Comalation } \\
\text { Cosffciant }\end{array}$ & $.148^{\prime \prime}$ & 1 & $.854^{\prime \prime}$ & $.730^{\circ}$ & $.733^{\prime \prime}$ & $.689^{\prime \prime}$ & $.701 "$ \\
\hline & \multirow{2}{*}{$\begin{array}{l}\text { Lack of logen } \\
\text { fimouroux }\end{array}$} & Sig (2-tailod) & 0.001 & . & 0 & 0 & 0 & 0 & 0 \\
\hline & & $\mathrm{N}$ & 520 & 520 & 520 & 520 & 520 & 520 & 520 \\
\hline & \multirow{3}{*}{$\begin{array}{l}\text { Lasc of bost } \\
\text { practice } \\
\text { gaidece }\end{array}$} & $\begin{array}{l}\text { Comenlation } \\
\text { Cosefficiant }\end{array}$ & $.185^{\prime \prime}$ & $854^{\prime \prime}$ & 1 & $.815^{\prime \prime}$ & $.823^{\prime \prime}$ & $.760^{\circ}$ & $.807^{\prime \prime}$ \\
\hline & & Sig (2-tailod) & 0 & 0 & . & 0 & 0 & 0 & 0 \\
\hline & & $\mathrm{N}$ & 520 & 520 & 520 & 520 & 520 & 520 & 520 \\
\hline & $\begin{array}{c}\text { Lack of } \\
\text { losderchip and } \\
\text { insorstices in } \\
\text { Sustainable }\end{array}$ & $\begin{array}{l}\text { Connalation } \\
\text { Coefficiant }\end{array}$ & . $157^{\prime \prime}$ & $.730^{\circ}$ & $.815^{\prime \prime}$ & 1 & $.829^{\circ}$ & $.760^{\circ}$ & "295" \\
\hline & \multirow[t]{2}{*}{$\begin{array}{l}\text { Denolopment } \\
\text { \& Reporting }\end{array}$} & Sigg (2-tailod) & 0 & 0 & 0 & & 0 & 0 & 0 \\
\hline & & $\mathrm{N}$ & 520 & 520 & 520 & 520 & 520 & 520 & 520 \\
\hline & \multirow{3}{*}{$\begin{array}{c}\text { Abrences of } \\
\text { eatarnal } \\
\text { motivation and } \\
\text { anforcement } \\
\text { mechanivem }\end{array}$} & $\begin{array}{l}\text { Correlation } \\
\text { Coesfficiant }\end{array}$ & $.169^{\circ}$ & $.753^{\prime \prime}$ & $.823^{\prime \prime}$ & $.829^{\prime \prime}$ & 1 & $.793^{\prime \prime}$ & $.74^{*}$ \\
\hline & & Sig (2-tailod) & 0 & 0 & 0 & 0 & & 0 & 0 \\
\hline & & $\mathrm{N}$ & 520 & 520 & 520 & 520 & 520 & 520 & 520 \\
\hline & \multirow{3}{*}{$\begin{array}{c}\text { Lack of } \\
\text { surarenoss mad } \\
\text { wndertanding } \\
\text { smanggit } \\
\text { stallabolders }\end{array}$} & $\begin{array}{l}\text { Complaltion } \\
\text { Cosfficient }\end{array}$ & $.137^{\prime \prime}$ & $.689^{\circ}$ & $.760^{*}$ & $.760^{\prime \prime}$ & $.793^{\prime \prime}$ & 1 & $869^{\prime \prime}$ \\
\hline & & Sig (2-tailod) & 0.002 & 0 & 0 & 0 & 0 & & 0 \\
\hline & & $\mathrm{N}$ & 520 & 520 & 520 & 520 & 520 & 520 & 520 \\
\hline & \multirow{2}{*}{$\begin{array}{l}\text { Lack of } \\
\text { araranow \& } \\
\text { understanding } \\
\text { of inplications } \\
\text { at tha top }\end{array}$} & $\begin{array}{l}\text { Consalation } \\
\text { Coefficiant }\end{array}$ & $.136^{\prime \prime}$ & $.701^{\prime \prime}$ & $.807^{\prime \prime}$ & $.795^{\prime \prime}$ & $.774^{\prime \prime}$ & $.869^{\prime \prime}$ & 1 \\
\hline & & Sig (2-tailod) & 0.002 & 0 & 0 & 0 & 0 & 0 & \\
\hline & $\begin{array}{c}\text { mamgemeil } \\
\text { lovel }\end{array}$ & $\mathrm{N}$ & 520 & 520 & 520 & 520 & 520 & 520 & 520 \\
\hline
\end{tabular}


Table 15. KMO and Bartlett's Test

Kaiser-Meyer-Olkin Measure of Sampling Adequacy.

0.934

Approx. Chi-Square

10897.363

Bartlett's Test of Sphericity

df

325

Sig.

0

Df-degree of freedom

\begin{tabular}{|c|c|c|c|c|c|c|c|c|}
\hline \multirow[t]{2}{*}{ Component } & \multicolumn{3}{|c|}{ Initial Eigen Values } & \multirow{2}{*}{$\begin{array}{c}\text { Extraction } \\
\text { Sums of } \\
\text { Squared } \\
\text { Loadings } \\
\text { Total }\end{array}$} & \multirow[b]{2}{*}{$\begin{array}{c}\text { \% of } \\
\text { Variance }\end{array}$} & \multirow[b]{2}{*}{$\begin{array}{c}\text { Cumulative } \\
\%\end{array}$} & \multirow{2}{*}{$\begin{array}{c}\text { Rotation } \\
\text { Sums of } \\
\text { Squared } \\
\text { Loadings } \\
\text { Total }\end{array}$} & \multirow[b]{2}{*}{$\begin{array}{l}\text { \% of } \\
\text { Variance }\end{array}$} \\
\hline & Total & $\begin{array}{c}\text { \% of } \\
\text { Variance }\end{array}$ & $\begin{array}{c}\text { Curmulative } \\
\%\end{array}$ & & & & & \\
\hline 1 & 13.42 & 51.625 & 51.625 & 13.423 & 51.625 & 51.625 & 6.232 & 23.971 \\
\hline 2 & 2.45 & 9.445 & 61.07 & 2.456 & 9.445 & 61.07 & 5.836 & 22.466 \\
\hline 3 & 1.58 & 6.091 & 67.161 & 1.584 & 6.091 & 67.161 & 4.193 & 16.128 \\
\hline 4 & 1.36 & 5.237 & 72.398 & 1.362 & 5.237 & 72.398 & 2.426 & 9.333 \\
\hline 5 & 1.1 & 4.255 & 76.653 & 1.106 & 4.255 & 76.653 & 1.242 & 4.776 \\
\hline 6 & 0.906 & 3.483 & 80.136 & & & & & \\
\hline 7 & 0.656 & 2.522 & 82.658 & & & & & \\
\hline 8 & 0.583 & 2.244 & 84.902 & & & & & \\
\hline 9 & 0.5 & 1.923 & 86.825 & & & & & \\
\hline 10 & 0.398 & 1.53 & 88.355 & & & & & \\
\hline 11 & 0.367 & 1.41 & 89.765 & & & & & \\
\hline 12 & 0.323 & 1.243 & 91.008 & & & & & \\
\hline 13 & 0.308 & 1.184 & 92.192 & & & & & \\
\hline 14 & 0.255 & 0.981 & 93.173 & & & & & \\
\hline 15 & 0.237 & 0.911 & 94.084 & & & & & \\
\hline 16 & 0.197 & 0.757 & 94.841 & & & & & \\
\hline 17 & 0.191 & 0.734 & 95.575 & & & & & \\
\hline 18 & 0.185 & 0.712 & 96.287 & & & & & \\
\hline 19 & 0.171 & 0.656 & 96.943 & & & & & \\
\hline 20 & 0.163 & 0.628 & 97.571 & & & & & \\
\hline 21 & 0.14 & 0.539 & 98.11 & & & & & \\
\hline 22 & 0.129 & 0.496 & 98.606 & & & & & \\
\hline 23 & 0.112 & $\begin{array}{r}0.43 \\
0.40\end{array}$ & 99.036 & & & & & \\
\hline 24 & 0.102 & 0.394 & 99.43 & & & & & \\
\hline 25 & 0.082 & 0.315 & 99.745 & & & & & \\
\hline 26 & 0.066 & 0.255 & 100 & & & & & \\
\hline
\end{tabular}

\begin{tabular}{|c|c|c|c|c|c|}
\hline & & & Component & & \\
\hline & 1 & 2 & 3 & 4 & 5 \\
\hline Income Enhancement & 0.866 & & & & \\
\hline Livelihood Generation & 0.839 & & & & \\
\hline Improve Employability & 0.816 & & & & \\
\hline Enhancing Sharebolder Value & 0.815 & & & & \\
\hline Price Stabilization & 0.813 & & & & \\
\hline $\begin{array}{l}\text { Regional Development } \\
\text { Rent }\end{array}$ & 0.804 & & & & \\
\hline Employment Generation & 0.786 & & & & \\
\hline Biodiversity Restoration & & 0.78 & & & \\
\hline Environmental Conservation & & 0.779 & & & \\
\hline Healthy people & & 0.747 & & & \\
\hline Greening Supply Chains & & 0.735 & & & \\
\hline Management of Scarce Resources & & 0.708 & & & \\
\hline Wildife Protection & & 0.7 & & & \\
\hline Development of Employees & & 0.677 & & & \\
\hline Active Volunteering & & 0.607 & & & \\
\hline Stakeholder Accountability & & 0.547 & & & \\
\hline Educated population & & 0.535 & & & \\
\hline Creating Educational and Charitable & & & 0.83 & & \\
\hline $\begin{array}{l}\text { Institutions } \\
\text { Community Development }\end{array}$ & & & 0.823 & & \\
\hline $\begin{array}{l}\text { Commminity Development } \\
\text { Enhancig Capacity }\end{array}$ & & & 0.792 & & \\
\hline Supply chain as a base of pyramid & & & 0.683 & & \\
\hline Forming Networks & & & 0.68 & & \\
\hline Youth \& Leadership & & & & 0.804 & \\
\hline Artisan \& Entrepreneurship Development & & & & 0.742 & \\
\hline Stakeholder Engagement & & & & 0.679 & \\
\hline Improving Health care and sanitation & & & & & 0.892 \\
\hline
\end{tabular}

Improving Health care and sanitation

Rotation Method: Varimax with Kaiser Normalizatio

a. Rotation converged in 8 iterations. 